\title{
BIPHASIC HYDROGENATION OF EUGENOL WITH RUTHENIUM AND RHODIUM NANOPARTICLES STABILIZED IN IONIC LIQUIDS
}

\author{
ISIS CRESPO ${ }^{a *}$, OLGIOLY DOMINGUEZ $^{b}$, PABLO BARICELLI ${ }^{c}$, MARGARITA BORUSIAK $^{c}$, OFELIA OMAÑA ${ }^{c}$, \\ WILLIAM CASTRO ${ }^{d}$ AND MERLIN ROSALES ${ }^{e}$
}

\author{
${ }^{a}$ Applied Chemistry Laboratory. Experimental Pedagogical University Libertador. Maracay 2104, Venezuela. \\ ${ }^{b}$ Department of Applied Chemistry. Faculty of Engineering. Central University of Venezuela. Caracas 1050, Venezuela. \\ ${ }^{c}$ Centre for Chemicals Research. Faculty of Engineering. University of Carabobo. Valencia 2001, Venezuela. \\ ${ }^{d}$ Laboratory of Bioinorganic Chemistry. Centre of Chemistry. Venezuelan Institute of Scientific Research. Caracas 1020-A, Venezuela. \\ ${ }^{e}$ Chemistry Department, Experimental Faculty of Science, University of Zulia, Maracaibo 4011, Venezuela.
}

\begin{abstract}
The purpose of this study was to evaluate on the catalytic activity nanostructured systems of ruthenium and rhodium stabilized in ionic liquids derived from

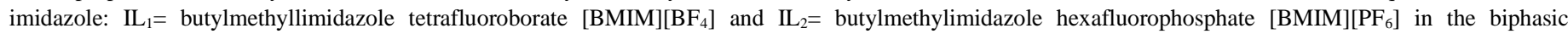
hydrogenation of eugenol under mild reaction conditions $\mathrm{T}=80^{\circ} \mathrm{C}, \mathrm{P}=100 \mathrm{psi}$ during 4 hours. The metallic nanoparticles (NPs-M) were synthesized using the ligand hydrogenation displacement reaction for the ruthenium III tris(acetylacetonate), $\left[\mathrm{Ru}(\mathrm{acac})_{3}\right]$, and bis- $\mu$-cloro-di(1,5-ciclooctadieno) dirhodium(I), $[\mathrm{Rh}(\mathrm{COD}) \mathrm{Cl}]_{2}$, showing a mean particle size between $\left(2.0 \pm \_0.2\right) \mathrm{nm}$ and $(4.0 \pm 0.2) \mathrm{nm}$. The nanostructured systems Rh/IL $2, \mathrm{Ru} / \mathrm{IL}_{2}$ and Ru/ $/ \mathrm{IL}_{1}$ show similar activities and different from the $\mathrm{Rh} / \mathrm{IL}_{1}$ system. On the other hand, the systems stabilized in the $\mathrm{IL}_{1}$ were more selective towards the formation of the 2-methoxy-4-propylphenol than the systems stabilized in the $\mathrm{IL}_{2}$. Nevertheless, in general, the catalysts were good for hydrogenating eugenol, resulting in $\mathrm{Rh} / \mathrm{IL}_{1}$ nanoparticles less reactive than $\mathrm{Rh} / \mathrm{IL}{ }_{2}$, $\mathrm{Ru} / \mathrm{IL}_{1}$ and $\mathrm{Ru} / \mathrm{IL}_{2}$.
\end{abstract}

Keywords: Nanoparticles, ionic liquids, biphasic hydrogenation, eugenol.

\section{INTRODUCTION}

Eugenol is part of the family of allylbenzenes, which in turn are part of the natural olefins readily available from biomass, forming alternative materials from renewable sources ${ }^{1}$. Eugenol is a phenolic derivative commonly known as clove essence, which has been used for several centuries in dental practice, due to its pharmacological properties, since it has many uses ${ }^{2}$ the oldest dental cement is a mixture zinc oxide-eugenol which has sedative and palliative property of pulpal pain, likewise the oil is used for spongy bleeding gums and gingivitis ${ }^{3,4}$. Within the many reported properties of eugenol are: neuroprotection ${ }^{5,4}$, inhibition for the biosynthesis of thromboxane ${ }^{6,4}$, anti-inflammatory, anticancer, antiischemic $^{7,4}$, antihistamine and antianaphylactic ${ }^{8,4}$. The cosmetic industry uses eugenol in soaps, perfumes, and shampoo production. In the food industry it is used to give aromas to prepared foods, alcoholic drinks, and soft drinks, among others. It is also used as a starting material to produce other compounds with higher aggregated value, such as 2-methoxy-4-propylphenol. This compound used as a raw material in the synthesis of 1,2-dimethoxy-4-propylbenzene, the pheromone of the male fruit fly (Dacus dorsalis Hendel) used in control of pests traps in many crops being 50\% more effective than methyl eugenol which was initially used by the farming community 9,10 .

The specialized literature reports the hydrogenation of eugenol and isoeugenol using Pt, Pd and $\mathrm{Ni}$ supported in $\mathrm{X}$ or $\mathrm{Y}$ zeolites. These systems favor the hydrogenation of eugenol, $\mathrm{Pd} / \mathrm{Y}$ having the most effective results with $98.24 \%$ selectivity towards 2-methoxy-4-propylphenol at $245^{\circ} \mathrm{C}$. Nevertheless, it is complex reaction due to the formation of the secondary products cis-isoeugenol and trans-isoeugenol ${ }^{11}$; another study using 2-methoxyl-4-allylphenol (eugenol), as a classic model compound of lignine, showed the aqueous phase catalysis of the phenolic monomer conversion to hydrocarbons using $\mathrm{Pd} / \mathrm{C}$ combined with HZSM-5 zeolites. The authors reported that the increase in acidity of the zeolites was due to the decrease in $\mathrm{Si} / \mathrm{Al}$ ratio. This influenced the catalytic performance obtaining a conversion of $86.5 \%$ with $73.4 \%$ selectivity towards 2-methoxyl-4propylphenol ${ }^{12}$

Furthermore, under other conditions the hydrogenation of eugenol with a porous metallic copper oxide catalyst has been reported, yielding $95 \%$ selectivity towards the formation of 2-methoxy-4-propylphenol with conversions greater than $53 \%$, under temperatures that oscillated from $22^{\circ} \mathrm{C}$ to $180^{\circ} \mathrm{C}$ and pressures between 1 and $4 \mathrm{MPa}$ for more than 3 hours ${ }^{13}$. It should be noted that, in the literature, multiple reports of the use of organometallic complexes of $\mathrm{Ru}$ and $\mathrm{Rh}$ in hydrogenation of natural olefins including eugenol can be found, however in most cases the reaction conditions are strong ${ }^{14}$.
The purpose of the present work is to study biphasic catalytic activity of rhodium and ruthenium nanoparticles, stabilized in ionic liquid, in the eugenol hydrogenation reactions, under mild reaction conditions.

\section{EXPERIMENTAL}

\subsection{Materials}

The eugenol (4-allyl-2-methoxyphenol) used as substrate for the biphasic hydrogenation was Sigma Aldrich technical grade $99 \%$ purity. The n-hexane used as solvent was $99 \%$ purity analysis from Merck. The evaluated ionic liquids were synthesized from Merck's 1-bromobutane with 98.9\% purity and SigmaAldrich 1-Methylimidazolium with $99 \%$ purity, as well as the inorganic salts of potassium hexafluorophosphate from Sigma - Aldrich with $98 \%$ purity and $95 \%$ sodium tetrafluoroborate of Alfa Aeser. For the syntheses of the nanostructured catalysts, the starting material used was the organometallic complexes $\left[\mathrm{Ru}(\mathrm{acac})_{3}\right] 99.9 \%$ purity from Strem Chemicals and $[\mathrm{Rh}(\mathrm{COD}) \mathrm{Cl}]_{2}$ which was previously synthesized from the $\mathrm{Rh} \mathrm{Cl}_{3} .3 \mathrm{H}_{2} \mathrm{O} 98 \%$ purity from Strem Chemicals.

\subsection{Equipment and Techniques}

The synthesis of nanoparticles was carried out in a $100 \mathrm{ml}$ Parr autoclave integrated to a Hewlett Packard model 4542 controller. For the catalytic biphasic hydrogenation of eugenol, a high pressure (3000 psi) $50 \mathrm{ml}$ batch Parr reactor equipped with sampler, agitation system (max: $1030 \mathrm{rpm}$ ), thermocouple and heating blanket coupled to a Parr 4842 Hewlett Packard controller was used.

The reaction products were analysed on a Hewlett Packard SERIES II 5890 gas chromatograph, fitted with a Chrompack brand fused silica capillary column model CP-Sil-24 CB (30 m, DI 0.32, 1.0 micron film), with nitrogen as a carrier gas, and an FID detector; A gas chromatograph with coupled mass spectrometer, Agilent Technologies 5975C VL MSD fitted with 30 meters column of $0.25 \mathrm{~mm}$ in diameter and 0.25 micrometers film and a Triple-Axis HP 5 detector was used to characterize the reaction products.

The chromatograph oven was programmed with a heating ramp using initial temperature of $160^{\circ} \mathrm{C}$, increased at $15^{\circ} \mathrm{C} / \mathrm{min}$ to $190^{\circ} \mathrm{C}$ and held at this temperature for $2 \mathrm{~min}$. The injector temperature was fixed at $190^{\circ} \mathrm{C}$ and the FID detector at $200^{\circ} \mathrm{C}$ the carrier gas pressure was held at $12.7 \mathrm{psi}$ and the run time was $20.67 \mathrm{~min}$.

The characterization of the ionic liquids was carried out by Fourier transform infrared spectroscopy (FTIR), the analyses were carried out in a Perkin Elmer Spectrum 1000 equipment. They were also characterized by means of nuclear magnetic resonance (NMR) in Brucker $500 \mathrm{Mhz}$ model. 
The nanoparticles characterization was carried out by a transmission electron microscopy (TEM), in an electronic transmission electron microscope FEI Type: Tecnai G^2 Spirit Biotwin, Model: 943205018411.

All the reactions were carried out under an inert argon (Ar) atmosphere using schlenk-type techniques for the handling of air-sensitive compounds. As for the solvents used tetrahydrofuran (THF), dichloromethane $\left(\mathrm{CH}_{2} \mathrm{Cl}_{2}\right)$, diethyl ether and $n$-hexane, all were dried by the traditional methods.

\subsection{Synthesis of de ionic liquids}

The synthesis of the ionic liquids was performed in two stages: (a) the cation formation followed the methodology proposed by Dupont et al ${ }^{15}$ allowing the reaction between the 1-methylimidazole and the alkyl halide (1-bromopentane or 1-bromododecane) in acetonitrile at room temperature for 72 hours. For the present study, the reaction between 1-methylimidazol and 1-bromobutane was carried out with constant stirring under inert atmosphere given that the [BMIM] $\mathrm{Br}$ product is hygroscopic and (b) the anion exchange proposed also by Dupont et al ${ }^{16}$. The [BMIM] $\mathrm{Br}$ obtained in stage (a) was divided into two portions, the first allowed to react with sodium tetrafluoroborate $\left(\mathrm{NaBF}_{4}\right)$ and the second portion with potasium hexafluorophosphate $\left(\mathrm{KPF}_{6}\right)$ in order to obtain butylmethylimidazolium tetrafluoroborato $\mathrm{IL}_{1}=[\mathrm{BMIM}]\left[\mathrm{BF}_{4}\right]$ and butylmethylimidazolium hexafluorophosphate $\mathrm{IL}_{2}=[\mathrm{BMIM}]\left[\mathrm{PF}_{6}\right]$ respectively. Table 1 summarizes the results of the characterization for each ionic liquid.

Table 1. Fourier transform infrared and ${ }^{1} \mathrm{H}$ nuclear magnetic resonance $\left({ }^{1} \mathrm{H}-\mathrm{NMR}\right)$ spectroscopy characterization results for the ionic liquids obtained.

\begin{tabular}{|c|c|c|c|}
\hline Ionic liquids (ILs) & & FTIR Spectral bands & ${ }^{1} \mathrm{H}-\mathrm{NMR} \delta$ (ppm) \\
\hline $\mathrm{IL}_{1}=[\mathrm{BMIM}]\left[\mathrm{BF}_{4}\right]$ & $\mathrm{BF}_{4}^{\ominus}$ & $\begin{array}{l}3160[\gamma(\mathrm{C}-\mathrm{H}) \text { aromatics }], 2965[\gamma(\mathrm{C}-\mathrm{H}) \text { aliphatic }] \text {, } \\
1570 \text { y } 1467[\gamma(\mathrm{C}=\mathrm{C}), 1061 \mathrm{U}(\mathrm{BF})\end{array}$ & $\begin{array}{l}8.70[\mathrm{~s}, 1 \mathrm{H}, \mathrm{H}(2)] ; 7.47[\mathrm{~s}, 1 \mathrm{H}, \mathrm{H}(4)] ; 7.37[\mathrm{~s}, 1 \mathrm{H}, \\
\mathrm{H}(4)][\mathrm{s}, 1 \mathrm{H}, \mathrm{H}(5)] ; 4.09\left[\mathrm{t}, 2 \mathrm{H},{ }^{1} \mathrm{~J}_{\mathrm{HH}} 6.6 \mathrm{~Hz} \mathrm{H}(6)\right] ; \\
3.85[\mathrm{~s}, 3 \mathrm{H}, \mathrm{H}(10)] ; 1.72 \text { y } 1.20[2 \mathrm{~m}, 4 \mathrm{H}, \mathrm{H}(7) \mathrm{y} \\
\mathrm{H}(8)] ; 0.83\left[\mathrm{t}, 3 \mathrm{H},{ }^{1} \mathrm{H}_{\mathrm{HH}}=5.31, \mathrm{H}(9)\right]\end{array}$ \\
\hline $\mathrm{IL}_{2}=[\mathrm{BMIM}]\left[\mathrm{PF}_{6}\right]$ & $\mathrm{pF}^{\ominus}$ & $\begin{array}{l}3177 \text { y } 3100[\mathrm{U}(\mathrm{C}-\mathrm{H}) \text { aromatics }], 2956,2936 \text { y } 2880 \\
{[\mathrm{U}(\mathrm{C}-\mathrm{H}) \text { Alifáticos }], 1576 \text { y } 1466[\mathrm{U}(\mathrm{C}=\mathrm{C}), 857} \\
\mathrm{U}(\mathrm{PF})\end{array}$ & $\begin{array}{l}8.66 \text { [br s, 1H, H(2)]; 7.47[br s, 2H, H(4) y } \\
\mathrm{H}(5)] ; 7.37 \text { [br s, H(6)]; 4.19[br s,3H, H(10)]; } 1.34 \\
{[\text { br s, H(9)]. }}\end{array}$ \\
\hline
\end{tabular}

The results reported in Table 1 reflect bands and signals that, when compared with that reported in the literature ${ }^{17,18}$, corroborate the obtaining of the desired ionic liquids.

\subsection{Synthesis of rhodium nanoparticles}

The synthesis of the nanosystems were carried out using the ligand hydrogenation displacement reaction of the organometallic $[\mathrm{RhCODCl}]_{2}$ precursor in the presence of the respective IL dissolved in THF as proposed by Domínguez et al ${ }^{19}$. The precursor was dissolved in THF and the corresponding IL in THF was added, at room temperature, in a $1 \mathrm{Rh}: 4 \mathrm{IL}$ ratio. This mixture was transferred to the Parr reactor, charged with $100 \mathrm{psi}_{2}$ pressure, and left under constant stirring at $60^{\circ} \mathrm{C}$. After 24 hours the reaction was stopped, a dark suspension of stabilized rhodium nanoparticles was obtained. The solvent was decanted via cannula and the remaining solid was washed thoroughly with dry THF in order to eliminate reaction by products and excess reactants. The rhodium nanosystems synthesized were dried under vacuum and stored under argon until later use. The nanosystems obtained will be named $\mathrm{Rh} / \mathrm{IL}_{1}$ and $\mathrm{Rh} / \mathrm{IL}_{2}$.

\subsection{Synthesis of ruthenium nanoparticles}

The synthesis of the ruthenium nanoparticles was carried out using Scholten et al ${ }^{20}$ reported method which implies the ligand hydrogenation displacement reaction of a salt or organometallic complex. In this case $\left[\mathrm{Ru}(\mathrm{acac})_{3}\right]$ and an ionic liquid as a stabilizing agent $\left(\mathrm{IL}_{1}\right.$ and $\left.\mathrm{IL}_{2}\right)$ with a molar ratio $1 \mathrm{Ru}$ : 7LI were previously dissolved in dry THF at room temperature, under an inert $\mathrm{Ar}$ atmosphere. Finally, the Parr reactor was charged with the mixture, with 58 psi of hydrogen $\left(\mathrm{H}_{2}\right)$ and left under constant agitation for 48 hours at $75^{\circ} \mathrm{C}$, after which the reactor was discharged, obtaining a dark suspension and fine black particles.

\subsection{Biphasic hydrogenation of eugenol}

Biphasic eugenol hydrogenations were performed using the nanostructured rhodium and ruthenium catalysts: $\mathrm{Rh} / \mathrm{IL}_{1}, \mathrm{Rh} / \mathrm{IL}_{2}, \mathrm{Ru} / \mathrm{IL}_{1}$ and $\mathrm{Ru} / \mathrm{IL}_{2}$. The methodology carried out by Melean et al ${ }^{14}$ was modified, such that the substrate was reacted with hydrogen in the presence of the nanostructured system stabilized with ionic liquid, an organic solvent was used to ensure the separation of the reaction products and the catalytic phase. In this sense, a Parr reactor was charged under inert atmosphere, with $6 \mathrm{mmol}$ of eugenol, $3 \mathrm{ml}$ of $\mathrm{n}$-hexane, 0.5 $\mathrm{ml}$ of ionic liquid $\left(\mathrm{IL}_{1}\right.$ and $\mathrm{IL}_{2}$ ) and $5 \mathrm{mg}$ of each of the Ru catalysts (nanoparticles). of $\mathrm{Ru} / \mathrm{IL}_{1}$ and $\mathrm{Ru} / \mathrm{IL}_{2}$ ) and $\mathrm{Rh}$ (nanoparticles of $\mathrm{Rh} / \mathrm{IL}_{1}$ and $\mathrm{Rh} /$ $\mathrm{IL}_{2}$ ) with $100 \mathrm{psi}$ of $\mathrm{H}_{2}$ at a temperature of $80^{\circ} \mathrm{C}$. The catalytic evaluations were carried out between 0.5 and 8 hours. At the end of the reaction time, the phases were separated for analysis by gas chromatography and mass spectroscopy.

\section{RESULTS AND DISCUSSION}

\subsection{Characterization of rhodium and ruthenium nanoparticles by TEM}

The bright field analysis by TEM for the nanostructured metal systems, stabilized in ionic liquids $\left(\mathrm{M}_{\mathrm{n}}-\mathrm{IL}_{\mathrm{n}}\right)$, confirmed that all the synthesized catalysts are made of nanometric particles. However, the micrographs did not yield a clear visualization of the interparticle planes, therefore, the indexation of the nanostructures could not be determined. $\mathrm{Rh} / \mathrm{IL}_{1}$ nanoparticle micrograph in Figure 1 (a) shows strong agglomeration of the particles, particles clusters, clusters of large particles overlapping the small particles, and few structures with hexagonal faceted particle definition are also appreciated. However, when viewing Figure 1 (b) corresponding to electron diffraction of the material, the presence of rings is observed, which allows us to infer the existence of very small nanoparticles in the material ${ }^{21}$, the bright dots present in the rings indicate the presence of a few faceted structures which difract in the same direction ${ }^{21}$. Given that the dispersion of the size of the nanoparticles is less than $12 \%$, it could be established that the material is homogenous as established in the specialized literature.

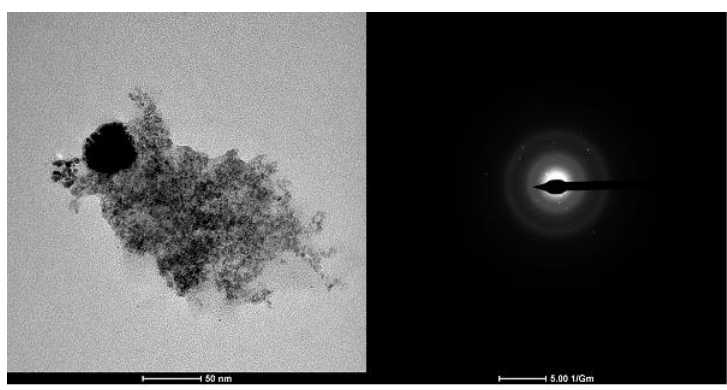

(a)

(b)

Figure 1. Images corresponding to micrographs of $\mathrm{Rh} / \mathrm{IL}_{1}$ nanoparticles by transmission electron microscopy (TEM) (a) clear field and (b) electron diffraction. 
Figure 2 shows the histogram of particle size distribution for the nanostructured system of $\mathrm{Rh} / \mathrm{IL} 1$ with a mean size distribution of $(2.6 \pm 0.2) \mathrm{nm}$.

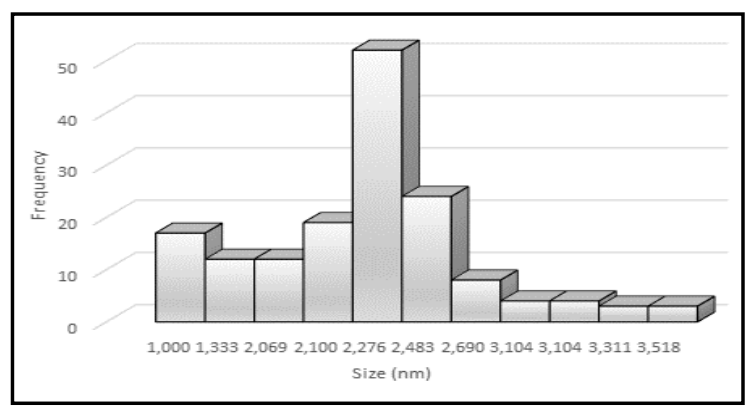

Figure 2. Particle size distribution histogram for $\mathrm{Rh} / \mathrm{LI}_{1}$ with a mean particle size of $(2.6 \pm 0.2) \mathrm{nm}$.

Figure 3 shows (a) bright field TEM analysis of the $\mathrm{Rh} / \mathrm{IL}_{2}$ nanoparticles, a large agglomeration can be observed, particle clusters, clusters of large particles overlapping small particles, some structures with hexagonal particle definition and appearance of ionic liquid encapsulating the particles. In Figure 3 (b) the electrons diffraction is very similar to that of $\mathrm{Rh} / \mathrm{IL}_{1}$ system although the presence of fewer and very diffuse bright dots in the diffraction rings, leads to infer that the faceted particles are scarcer than in the $\mathrm{Rh} / \mathrm{IL}_{1}$ system. Once again this analysis allows the establishment of the nanomaterial size homogeneity.

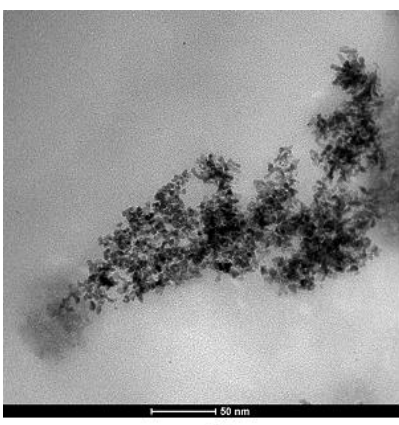

(a)

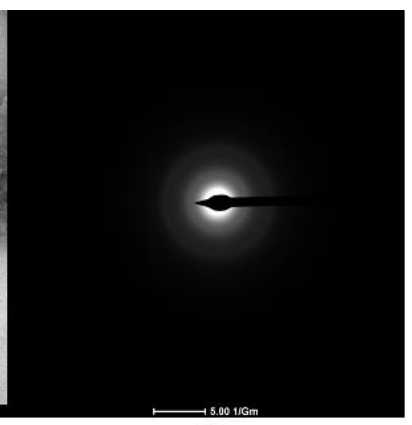

(b)
Figure 3. Images corresponding to micrographs of $\mathrm{Rh} / \mathrm{IL}_{2}$ nanoparticles by transmission electron microscopy (TEM) (a) clear field and (b) electron diffraction.

Through the particle size distribution histogram of this system (Figure 4), we determined that the nanoparticles have an average size of $(4.0 \pm 0.2) \mathrm{nm}$, unlike the size distribution obtained for the $\mathrm{Rh} / \mathrm{IL}_{1}$ in this case the distribution is bimodal, maintaining the nanometric scale. In this sense, when compared with what is reported in the literature for the synthesis of rhodium nanoparticles, particle sizes vary from $2 \mathrm{~nm}{ }^{22}$, while other investigations in which rhodium nanoparticles stabilized in ionic liquids were synthesized from the organometallic complex $[\mathrm{Rh}(\mu-\mathrm{Cl})(\mathrm{COD})]_{2} 2.13$ - $6.4 \mathrm{~nm}$ nanoparticles were obtained ${ }^{19}$. Thus, the nanoparticles obtained in this investigation are within the reported size.

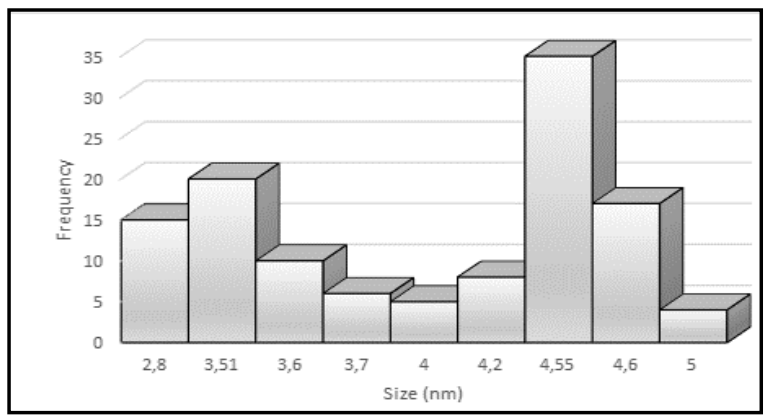

Figure 4. $\mathrm{Rh} / \mathrm{IL}_{2}$ Histogram of nanoparticles with particle size distribution of $(4.0 \pm 0.2) \mathrm{nm}$.
The bright field TEM analysis for $\mathrm{Ru} / \mathrm{IL}_{1}$ system shown in Figure 5 (a) reveals spherical and oval shape nanoparticles, strong agglomeration of this system and less ordered crystallinity. While in the electron diffraction visualized in Figure 5 (b), the presence of well-defined diffraction rings with bright dots is observed, which allows inferring the coexistence of very small nanoparticles and larger particles that were not possible to measure in the light field micrographs. Therefore, the amount of bright dots found in the rings shows that there is percentage of particles that are faceted; consequently they diffract in particular angles, which show heterogeneity in the material.

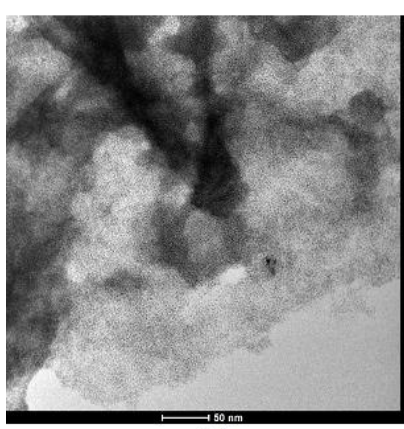

(a)

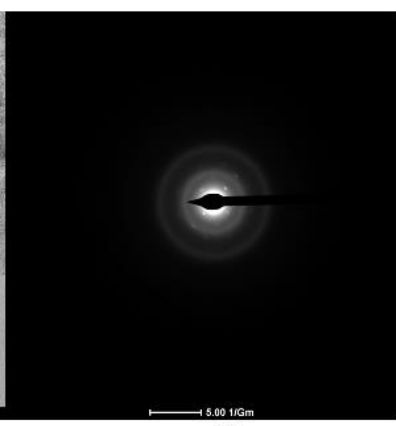

(b)
Figure 5. Images corresponding to micrographs of $\mathrm{Ru} / \mathrm{IL}_{1}$ nanoparticles by transmission electron microscopy (TEM) (a) clear field and (b) electron diffraction.

The particle size distribution histogram in Figure 6 for the nanostructured system of $\mathrm{Ru} / \mathrm{IL}_{1}$ is shows an average particle size of $\left(2.0 \pm \_0.2\right) \mathrm{nm}$, defining it as a nanomaterial.

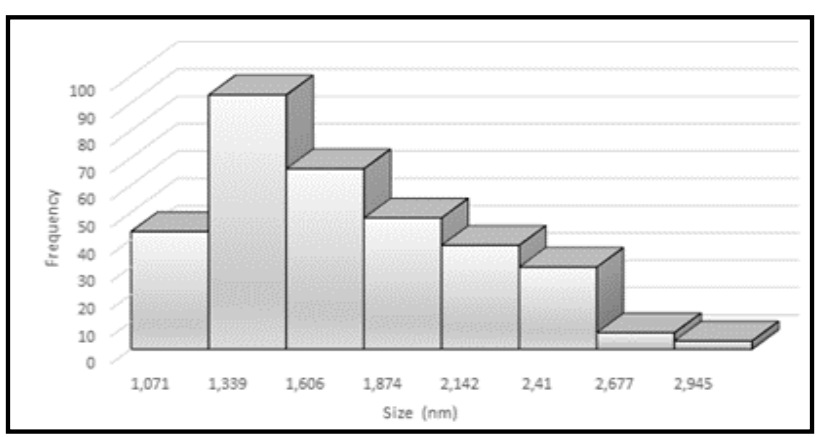

Figure 6. Histogram of $\mathrm{Ru} / \mathrm{IL}_{1}$ nanoparticles: particle size distribution $(2.0 \pm 0.2) \mathrm{nm}$

In Figure 7 (a) the bright field TEM micrograph of $\mathrm{Ru} / \mathrm{IL}_{2}$ strong agglomeration is observed with small particle clusters evenly distributed. Although for this material the mean distribution size of $(2.1 \pm 0.1) \mathrm{nm}$ is very similar to that found $\mathrm{Ru} / \mathrm{IL}_{1}$, its worth noting the lack of bright dots in the electron difraction image (b). This leads us to infer that this material is composed only of small nanoparticles.

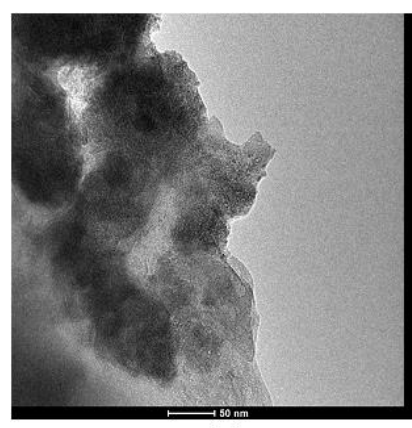

(a)

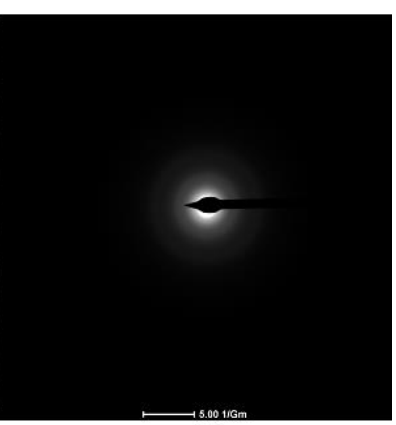

(b)
Figure 7. Images corresponding to micrographs of $\mathrm{Ru} / \mathrm{IL}_{2}$ nanoparticles by transmission electron microscopy (TEM) (a) clear field and (b) electron diffraction. 
The histogram of particle size distribution for $\mathrm{Ru} / \mathrm{IL}_{2}$ nanoparticles is shown In Figure 8, once again confirming the nanometric character of the catalyst.

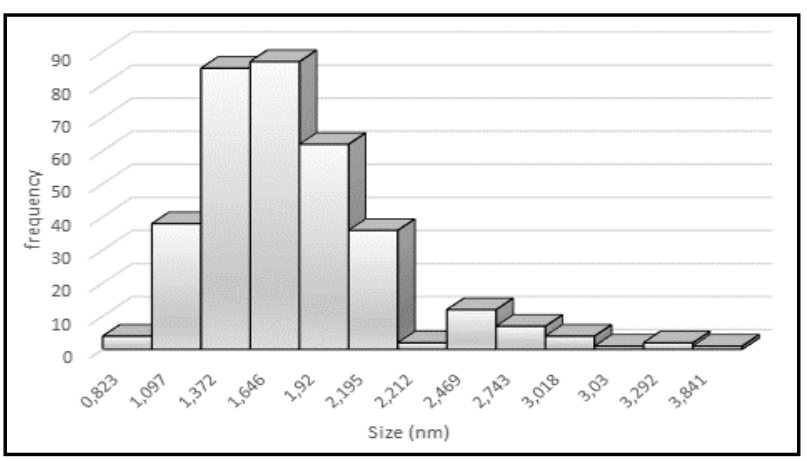

Figure 8. Histogram of $\mathrm{Ru} / \mathrm{IL}_{2}$ nanoparticles: particle size distribution $(2.1 \pm 0.1) \mathrm{nm}$

Comparing the ruthenium nanosystems synthesized here $\left(\mathrm{Ru} / \mathrm{IL}_{1}\right.$ and $\left.\mathrm{Ru} / \mathrm{IL}_{2}\right)$ with those reported in the literature where $\mathrm{Ru}(0)$-NPs nanoparticles were obtained from [Ru (COD) (2-methylalyl) 2] in $\mathrm{IL}=\mathrm{nHM}_{2} \cdot \mathrm{NTf}_{2}$ with average size of $(2.0 \pm 0.3) \mathrm{nm}{ }^{23}$; and $\mathrm{Ru}(0)$-MPs nanoparticles made in other ionic liquids where the average size is in the range of $(2-3) \mathrm{nm}^{24}$, it is confirmed that the synthesis method starting from the $\left[\mathrm{Ru}(\mathrm{acac})_{3}\right]$ precursor was effective in obtaining nanoparticles with similar sizes.

\subsection{Biphasic hydrogenation of eugenol}

Once the catalytic tests corresponding to the biphasic hydrogenation of eugenol were carried out, the gas chromatography/ mass chromatography (GC /MS) and gas chromatography (GC) analysis corroborated the presence of the substrate (eugenol) and three products.
In literature these correspond to: (1) eugenol, (2) 2-methoxy-4-propylphenol, (3) cis-isoeugenol and (4) trans-isoeugenol. The resulting 2-methoxy-4propylphenol (2) is the main hydrogenation product. The reaction scheme in Figure 9 displays the aforementioned products that were confirmed by chromatography and agree with that reported by Kadarohman ${ }^{25}$.<smiles>C=CCc1ccc(O)c(OC)c1</smiles>

(1)<smiles>C/C=C/c1ccc(O)c(OC)c1</smiles>

(3) y (4)
Figure 9. Reaction scheme for the biphasic hydrogenation catalysis of eugenol ref ${ }^{13}$.

In the present work we studied the catalytic activity of each nanostructured system $\mathrm{Rh} / \mathrm{IL}_{1}, \mathrm{Rh} / \mathrm{IL}_{2}, \mathrm{Ru} / \mathrm{IL}_{1}$ y Ru/ $\mathrm{IL}_{2}$ a 0,$5 ; 1 ; 2 ; 3 ; 4$ and 8 hours reaction time. In Figure 10 we can appreciate the biphasic hydrogenation profile of each catalyst studied. $\mathrm{Rh} / \mathrm{IL}_{2}, \mathrm{Ru} / \mathrm{IL}_{1}$ and $\mathrm{Ru} / \mathrm{IL}_{2}$ have the same behavior, whereas $\mathrm{Rh} / \mathrm{IL}_{1}$ have an appreciably lower catalytic activity. $\mathrm{Ru} / \mathrm{IL}_{1}$ and $\mathrm{Ru} / \mathrm{IL}_{2}$ systems reach maximum conversion, above $97 \%$, after four hours; $\mathrm{Rh} / \mathrm{IL}_{2}$ achieves $81 \%$ conversion in the same time without reaching its plateau; whereas for $\mathrm{Rh} / \mathrm{IL}_{1}$ only reaches $53 \%$ conversion, and even after 8 hours reaction it only achieves $60 \%$ conversion. These results show that the ruthenium nanosystems here studied are more active than the rhodium counterparts for the biphasic catalytic hydrogenation of eugenol. Nevertheless, the literature reports the hydrogenation reaction of myrcene to be less active with ruthenium organometallic complexes than rhodium complexes ${ }^{26}$. The difference in activity between the two metals could well be ascribed to the nanometric characteristics of the materials here studied.

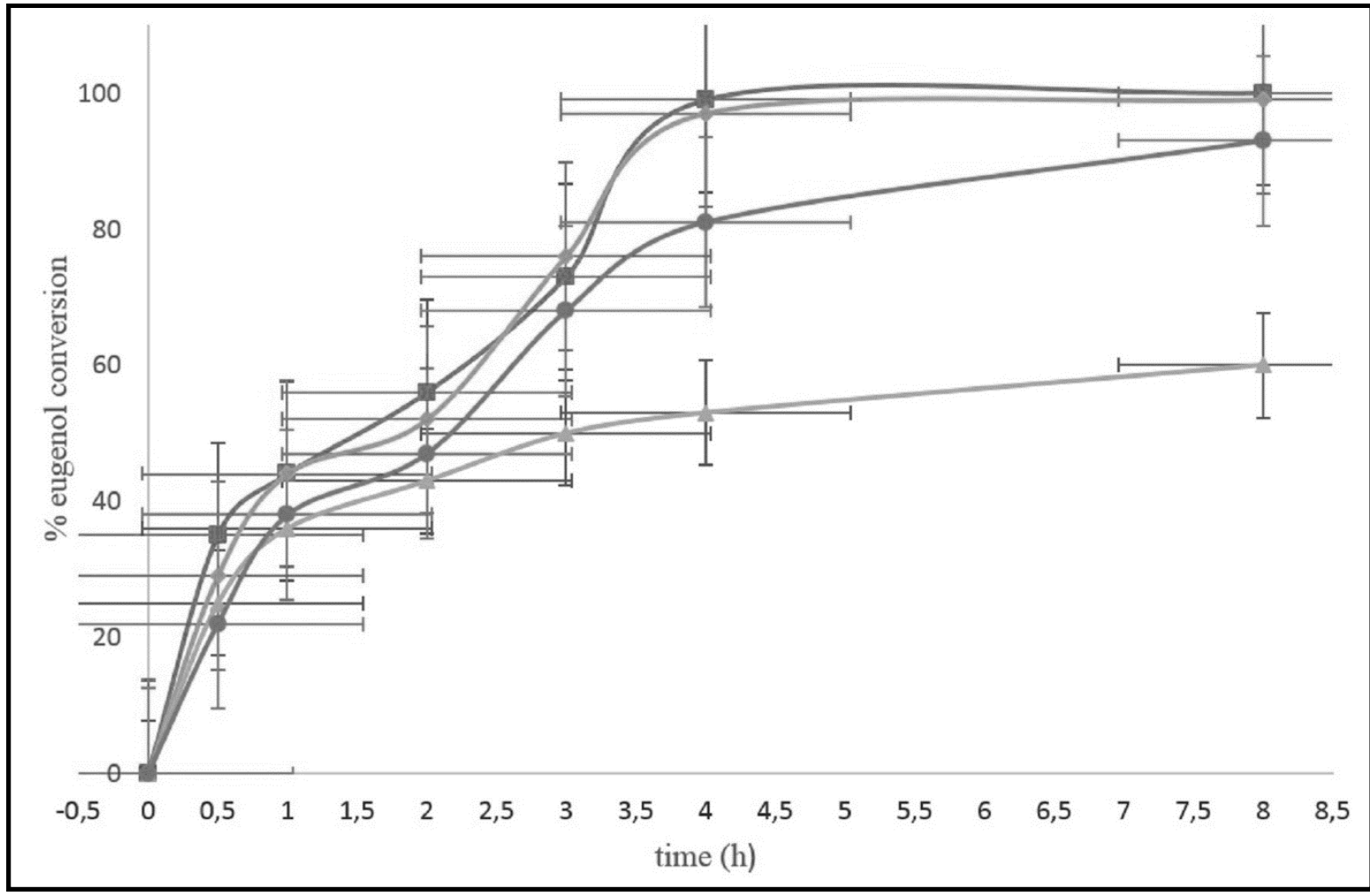

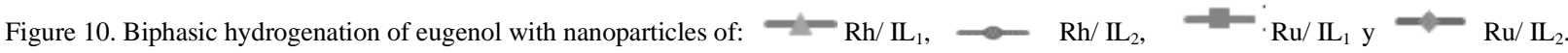

In the study of the selectivity of the catalytic systems towards 2-methoxy-4-propylphenol (Table 2) the Ru/LI y Rh/LI systems show selectivities very near $100 \%$, during all reaction times; whereas those catalysts stabilized in $\mathrm{IL}_{2}$ showed varied selectivities above $84 \%$. Then again, the observed change in the formation of products can be attributed to the intrinsic characteristics of the nanostructured catalyst. 
Table 2. Conversion and selectivity for the hydrogenation of eugenol using $\mathrm{Rh} / \mathrm{IL}_{1}, \mathrm{Rh} / \mathrm{IL}_{2}, \mathrm{Ru} / \mathrm{IL}_{1}$ and $\mathrm{Ru} / \mathrm{IL}_{2}$ nanoparticles.

\begin{tabular}{|c|c|c|c|c|c|}
\hline Nanoparticles & $\begin{array}{l}\text { Time } \\
\text { (h) }\end{array}$ & $\begin{array}{c}\text { Conversion } \\
(\%)\end{array}$ & $\begin{array}{c}\text { Selectivity }^{[\mathrm{a}]} \\
(\%) \\
(2)\end{array}$ & $\begin{array}{c}\text { Selectivity }^{[\mathrm{a}]} \\
(\%) \\
(3)\end{array}$ & $\begin{array}{c}\text { Selectivity }^{[a]} \\
(\%) \\
(4)\end{array}$ \\
\hline & 0,5 & 25 & 100 & - & - \\
\hline & 1 & 36 & 100 & - & - \\
\hline \multirow[t]{6}{*}{$\mathrm{Rh} / \mathrm{IL}_{1}$} & 2 & 43 & 100 & - & - \\
\hline & 3 & 50 & 100 & - & - \\
\hline & 4 & 53 & 97 & 1 & 2 \\
\hline & 8 & 60 & 100 & - & - \\
\hline & 0,5 & 22 & 100 & - & - \\
\hline & 1 & 38 & 84 & 9 & 7 \\
\hline \multirow[t]{6}{*}{$\mathrm{Rh} / \mathrm{IL}_{2}$} & 2 & 47 & 91 & 2 & 7 \\
\hline & 3 & 68 & 96 & 2 & 2 \\
\hline & 4 & 81 & 94 & 3 & 3 \\
\hline & 8 & 93 & 97 & 1 & 2 \\
\hline & 0,5 & 35 & 100 & - & - \\
\hline & 1 & 44 & 100 & - & - \\
\hline \multirow[t]{6}{*}{$\mathrm{Ru} / \mathrm{IL}_{1}$} & 2 & 56 & 100 & - & - \\
\hline & 3 & 58 & 100 & - & - \\
\hline & 4 & 99 & 99 & 0,4 & 0,6 \\
\hline & 8 & 100 & 99 & 0,4 & 0,6 \\
\hline & 0,5 & 29 & 90 & 4 & 6 \\
\hline & 1 & 44 & 96 & 1 & 3 \\
\hline \multirow[t]{4}{*}{$\mathrm{Ru} / \mathrm{IL}_{2}$} & 2 & 52 & 92 & 3 & 5 \\
\hline & 3 & 76 & 97 & 1 & 2 \\
\hline & 4 & 97 & 99 & 0 & 1 \\
\hline & 8 & 99 & 94 & 2 & 4 \\
\hline
\end{tabular}

Conditions: $\mathrm{Rh} / \mathrm{IL}_{1}, \mathrm{Rh} / \mathrm{IL}_{2}, \mathrm{Ru} / \mathrm{IL}_{1}$ and $\mathrm{Ru} / \mathrm{IL}_{2}=0.005$ gr, $\mathrm{n}$-hexane $=3 \mathrm{ml}$, $\mathrm{IL}_{1}=[\mathrm{BMIM}]\left[\mathrm{BF}_{4}\right]$ and $\mathrm{IL}_{2}=[\mathrm{BMIM}]\left[\mathrm{PF}_{6}\right]=0.5 \mathrm{ml}$, substrate $(1)$ eugenol= $1 \mathrm{gr}$, $\mathrm{P}=100 \mathrm{psi}, \mathrm{T}=80^{\circ} \mathrm{C}$. [a] Selectivity towards hydrogenated species (2) 2methoxy-4-propylphenol, (3) cis-isoeugenol and (4) trans-isoeugenol.

The difference in terms of conversions and selectivities could be attributed to a synergy between the substrate and the catalyst. This led us to think, at first, that a small particle size could be directly related to these results since the decrease in particle size causes a large amount of atoms to be available as active sites on the surface of the particles ${ }^{27,28,29}$. However, there is only a size difference for the $\mathrm{Rh} / \mathrm{IL}_{1}$ and $\mathrm{Rh} / \mathrm{IL}_{2}$ nanoparticles, while there are no size differences for the $\mathrm{Ru} / \mathrm{IL}_{1}$ and $\mathrm{Ru} / \mathrm{IL}_{2}$ nanoparticles; therefore apparently the greatest influence comes from the ionic liquid.

It has been observed that the size of the M-NPs in ILs, is influenced by the self-organization of these organic salts ${ }^{30}$, so in principle, this size can be modulated by the chain length $\mathrm{N}$-alkyl in the imidazolium cation ${ }^{31}$, the volume of the anion ${ }^{32}$, the temperature ${ }^{33}$ or the coordinating capacity of the anion ${ }^{34}$. Now in Table 3 it is observed that the Ru nanoparticles were more active than those of $\mathrm{Rh}$ in the biphasic hydrogenation of eugenol; however the nanostructured systems $\mathrm{Rh} / \mathrm{IL}_{2}, \mathrm{Ru} / \mathrm{IL}_{2}$ and $\mathrm{Ru} / \mathrm{IL}_{1}$ show similar activities and different from the $\mathrm{Rh} / \mathrm{IL}_{1}$ system. On the other hand, the systems stabilized in the $\mathrm{IL}_{1}$ were more selective towards the formation of the product (2) than the systems stabilized in the $\mathrm{IL}_{2}$. This result is interesting considering that the cations are the same and only differed in the anions, being the most voluminous anion $\left(\mathrm{PF}_{6}{ }^{-}\right)$the least selective, while the less bulky anion $\left(\mathrm{BF}_{4}^{-}\right)$was more selective, which makes it clear that for these nanocatalysts the steric stabilization could be the effect responsible for the selectivity.
Table 3. Conversions, activities and particle size for the biphasic hydrogenation of eugenol using rhodium and ruthenium nanoparticles stabilized in $\mathrm{IL}_{1}$ and $\mathrm{IL}_{2}$.

\begin{tabular}{|c|c|c|c|c|}
\hline Catalyst & $\begin{array}{c}\text { Particle size } \\
(\mathbf{n m})\end{array}$ & $\begin{array}{c}\text { Conversion } \\
(\boldsymbol{\%})\end{array}$ & $\begin{array}{c}\text { Selectivity } \\
\text { [a] }(\boldsymbol{\%})\end{array}$ & $\begin{array}{c}\text { TOF } \\
\mathbf{h}^{-\mathbf{1}}\end{array}$ \\
\hline $\mathrm{Rh} / \mathrm{IL}_{1}$ & $2.6 \pm 0.2$ & 53 & 97 & 1596 \\
\hline $\mathrm{Rh} / \mathrm{IL}_{2}$ & $4.0 \pm 0.2$ & 81 & 94 & 2440 \\
\hline $\mathrm{Ru} / \mathrm{IL}_{1}$ & $2.0 \pm \_0.2$ & 99 & 99 & 2982 \\
\hline $\mathrm{Ru} / \mathrm{IL}_{2}$ & $2.1 \pm 0.1$ & 97 & 99 & 2922 \\
\hline
\end{tabular}

Conditions: $\mathrm{Rh} / \mathrm{IL}_{1}, \mathrm{Rh} / \mathrm{IL}_{2}, \mathrm{Ru} / \mathrm{IL}_{1}$ and $\mathrm{Ru} / \mathrm{IL}_{2}=0.005$ gr, n-hexane $=3 \mathrm{ml}$, $\mathrm{IL}_{1}=[\mathrm{BMIM}]\left[\mathrm{BF}_{4}\right]$ and $\mathrm{IL}_{2}=[\mathrm{BMIM}]\left[\mathrm{PF}_{6}\right]=0.5 \mathrm{ml}$, substrate (eugenol) $=1 \mathrm{gr}$, T0 $80^{\circ} \mathrm{C}, \mathrm{P}=100 \mathrm{psi}, \mathrm{t}=4 \mathrm{~h}$, [a] selectivity=2- methoxy-4-propylphenol.

This can be explained by the fact that ionic liquids are best described as supramolecular fluids that are organized as aggregates of the type [(DAI) $\left.(\mathrm{X})_{\mathrm{xn}}\right]^{\mathrm{n}+}\left[(\mathrm{DAI})_{\mathrm{xn}}(\mathrm{X})_{\mathrm{x}}\right]^{\mathrm{n}-}$ in which, DAI is, for example, 1, 3- dialkylimidazolium (cation) and $\mathrm{X}^{-}$is the anion ${ }^{35}$. The anionic aggregates of the ionic liquid [(DAI $\left.{ }_{\mathrm{xn}}(\mathrm{X})_{\mathrm{x}}\right]^{\mathrm{n}-}$ are responsible for the stabilization of small particles $(1-10 \mathrm{~nm})$, which shows electronic deficiency on their surface. The larger particles are stabilized through the interaction with the cationic aggregates of the ionic liquid [(DAI) $\times$ (X) $\left.{ }_{x n}\right]^{\mathrm{n}+}{ }^{36}$. In this particular case, for $\mathrm{Rh} / \mathrm{IL}_{1}, \mathrm{Rh} / \mathrm{IL}_{2}, \mathrm{Ru} / \mathrm{IL}_{1}$ and $\mathrm{Ru} / \mathrm{IL}_{2}$ nanoparticles, it is probably the adsorption of the supramolecular aggregates ${ }^{28}$ of the ionic liquid on the metal surface (double layer of aggregates) that favors the coordination of the substrate towards the active sites. Despite the steric and size factors, a greater contact, and consequently a higher formation and selectivity towards the main product ${ }^{29,37}$ is aided. However, in general, the catalysts were good for hydrogenating eugenol, resulting in $\mathrm{Rh} / \mathrm{IL}_{1}$ nanoparticles less reactive than $\mathrm{Rh} / \mathrm{IL}_{2}, \mathrm{Ru} / \mathrm{IL}_{1}$ and $\mathrm{Ru} / \mathrm{IL}_{2}$.

\subsection{Mercury drop test}

In order to test the absence of metallic particles in the reaction mixture, the biphasic hydrogenation of the eugenol was tested by adding a drop of liquid mercury to the reaction mixture. The results obtained: (a) under the established study conditions for the $\mathrm{Ru} / \mathrm{IL}_{1}=0.005 \mathrm{gr}$, $\mathrm{n}$-hexane $=3 \mathrm{ml}, \mathrm{IL}_{1}=[\mathrm{BMIM}]\left[\mathrm{BF}_{4}\right]$ and $\mathrm{IL}_{2}=[\mathrm{BMIM}]\left[\mathrm{PF}_{6}\right]=0.5 \mathrm{ml}$, substrate $($ eugenol $)=1 \mathrm{gr}, \mathrm{T}=80^{\circ} \mathrm{C}, \mathrm{P}=100$ $\mathrm{psi}, \mathrm{t}=4 \mathrm{~h}$, yielded $99 \%$ conversion and $99 \%$ selectivity towards the formation of 2-methoxy-4-propylphenol; (b) adding a drop of mercury to the reaction mixture under the conditions mentioned above did not generate any products, and $100 \%$ of the substrate (eugenol) was recovered. This indicates that probably the active metal nanoparticles stabilized in the ionic liquids formed an amalgam with mercury inhibiting biphasic catalysis, thus corroborating that metallic nanoparticles are responsible for the conversions and selectivities towards 2methoxy-4-propylphenol ${ }^{38,39}$.

\section{CONCLUSIONS}

By the method of reduction and ligand displacement ruthenium and rhodium nanoparticles stabilized in ionic liquids nanoscale ILs corresponding to that reported in the literature were synthesized. The synthesized nanometric systems were active for the hydrogenation of eugenol biphasic under mild reaction conditions. There are no reports in the literature of biphasic catalysis with nanometric systems of these metals for the hydrogenation of eugenol. Ruthenium nanosystems in this study were more active than the rhodium counterparts for the biphasic catalytic hydrogenation of eugenol, under the mild conditions used. Both metals stabilized in the ionic liquids, under the mild conditions described herein, are highly selective towards the product 2-methoxy-4-propylphenol.

\section{ACKNOWLEDGMENTS}

The authors wish to thank the Laboratory of Organometallic Synthesis (SOM) of the School of Chemistry, Faculty of Sciences of the Central University of Venezuela for its material contribution and support in the synthesis of nanoparticles; also to the Chemical Research Center (CIQ) of the Faculty of Engineering of the University of Carabobo (UC) for allowing the development of research and to the Microscopy Laboratory of the Chemical Center, Venezuelan Institute of Scientific Research (IVIC). 


\section{REFERENCES}

1. P. Baricelli, L. Melean, M. Rodríguez, M. dos Santos, M. Rosales and E. Escalante. Biphasic Hydrogenation and Hydroformylation of Natural Olefins with a Binuclear Rhodium Complex in Ionic Liquid/Toluene. J. Chem. Eng. 7, 299-305, (2013).

2. R. González. Eugenol: propiedades farmacológicas y toxicológicas. Ventajas y desventajas de usos. Rev. Cubana Estomatol. V.9,nº2. (2002).

3. K. Date, P. Kulkarni. Assessment of Rasadanti in various oral disorders. Ayuved Res. Pap, II, 165-175, (1995).

4. Bhimrao. K. Jadhau; Kishanchandra. R. Khandelwal; Avant. R. Ketkar; Sambhaji. S. Pisal. Formulation and evaluation of Mucoadhesive tablets containing eugenol for the treatment of periodontal diseases. Vol 30, $\mathrm{N}^{\circ} 2$, pp. 195-203, (2004).

5. M. Wie, M. Won, J. Lee; H. Suh; D. Song, Y. Kin. Eugenol protects neuronal cells from excitotoxic and oxidative injury in primary cortical cultives. Neurosci. Lett. 225(2), 93-96, (1997).

6. S. Laekeman, V. Hoof, A. Haemers, V. Berghe, A. Harman, A. Vlietink. Eugenol a valuable compound for in-vitro experimental research and worthwhile for further in vivo investigation phytother. Res. 4(3); 99-96. (1990).

7. Atsusane, T. Clove oil or dehydroeugenol for controlling oxygen in the human body. Japan. Kokai Tokkyo Koho, 227, 6, (1991).

8. Hiroaki, N; Ryui, U; Nozamik, K.S; Kenji, K.J. Role of endotheliom and adventitia on eugenol induced relaxation of rabbit ear artery precontracted by histamine smooth muscle. Res.1998, 34(3), (123-127).

9. Demilo AB, Cunningham RT \& McGovern TP. Structural of Methyl Eugenol and Their Attractiveness to the Oriental Fruit Fly (Diptera: Tephritidae). Journal of Economic Entomology. 87 (4): 957-964, (1994).

10. A. Kadarohman. Mempelajari Mekanisme Dan Kontrol Reaksi Isomerisasi Eugenol Menjadi Isoeugenol. Thesis of FMIPA UGM Yogyakarta: Unpublication. (1994)

11. A. Kadarohman. Isomerisasi, Hidrogenasi Eugenol, Dan Síntesis Turunan Kariofilena. Dissertation of FMIPA UGM Yogyakarta: Unpublication. (2003).

12.Z. Cong, X. Jing, S. Liang, X. Hongchuan, L. Sen, X. Lishu, L. Xuebing. Aqueous-phase hydrodeoxygenation of lignin monomer eugenol:Influence of Si/Al ratio of HZSM-5 on catalytic performances. Catal. Today (2014).

13. L. Petitjean , R. Gagne, E. Beach., D. Xiao and P. Anastas. Highly selective hydrogenation and hydrogenolysis using a copper-doped porous metal oxide catalyst. Green Chemistry, 18(1), 150-156, (2016).

14. L. Meleán, P. Baricelli, M. Rosales. Hidrogenación e hidroformilación de terpenos, alilbencenos $\mathrm{y}$ aldehídos $\alpha, \beta$ insaturados con complejos hidrosolubles de Rodio y Rutenio en medio bifásico. Tesis Doctoral. UCV, Ven, 8-241, (2010).

15. J. Dupont, C. Consorte, P. Suarez, R. De Souza. Preparation of 1-butyl-3methyl imidazolium-based room temperature ionic liquids. $[1 \mathrm{H}-$ Imidazolium, 1-butyl-3-methyl-, chloride (1-); 1H-Imidazolium, 1-butyl-3methyl-, tetrafluoroborate (1-); 1H-Imidazolium, 1-butyl-3-methyl-, hexafluorophosphate (1-) ]. Org. Syntheses. Coll. 10; 184, (2004).

16. J. Dupont, C. Consorti,P. Suarez, R. De Souza. Preparation of 1-butyl-3methyl imidazolium-based room temperatura Ionic liquids. Org. Synth, 79, 236. (2002)

17. X. Dan-Qian, H. Zhi-Yan, L. Wei-Wei, L. Shu-Ping, X. Zhen-Yuan. Hydrogenation in ionic liquids: An alternative methodology toward highly selective catalysis of halonitrobenzenes to corresponding haloanilines. Journal of molecular catalysis A Chemical 235; 137-142. (2005).

18. P. Suarez, J. Dullius; S. Einloft; R. de Souza and J. Dupont; Org. Syntheses. The use of new ionic liquids in two-phase catalytic hidrogenation reaction by Rhodium complexes; Elsivier science, 2 ; 1217-1219, (1996).

19. O. Domínguez, E. Escalante, D. Manaure; E. Cañizales, R. Machado. Actividad catalítica de nanopartículas de Rodio estabilizados en diferentes líquidos iónicos en reacciones de hidrogenación del ciclohexeno y del benceno. Revista de la facultad de ingeniería UCV, 27(3), 95-104, (2012).

20. Jackson D. Scholten, Martin H.G. Prechtl, and Jairton Dupont. Formation of Nanoparticles Assisted by Ionic Liquids. Handbook of Green Chemistry Volume 8: Green Nanoscience, First Edition (2012).

21. M. Sosa, M. Bullón, C. Urbina, G. Jorge, J. Martínez. Estudio de nanopartículas bimetálicas de Rh-Pd sintetizadas por vía electroquímica. Avances en ciencias e ingeniería. Research Gate, Vol 2(3), pp.889-99. (2011).

22. M. Ramírez, K. Philippot, B. Chaudret. Influencia del medio de reacción en la estabilización de nanoestructuras de Rodio. Ingeniería investigación y tecnología, 16 (2). 225-237. (2015).

23. M. Prechtl, P. Campbell, J. Scholten, G. Frases, G. Machado, C. Santini, J. Dupont, Y. Chauvin. Imidazolium ionic liquids as promoters and stabilising agents for the preparation of metal( 0 ) nanoparticles by reduction and decomposition of organometallic complexes. Nanoscale, 2, 2601-2606, (2010).

24. M. Prechtl, M Scariot, J. Sholten, G. Machado, S. Texeira and J. Dupont Nanoscale $\mathrm{Ru}(0)$ particles Arene hydrogenation catalysts in imidazolium ionic liquids inorganic chemistry, vol 47, $\mathrm{N}^{\circ} 19,(2008)$.

25. A. Kadarohman. Kinetics of complex reaction of eugenol hydrogenation to 2-methoxy-4-propylphenol in $\mathrm{Pd} / \mathrm{Y}$ catalyst. Journal ILMU DASAR.vol11,N $\mathrm{N}^{\circ} 1,1-7 .(2010)$.

26. Speziali, M. G; Moura, F.C.C; Robles-Dutenhefner, P.A; Araujo. M.H Gusevskaya, E.V;Dos Santos. E.N. Selective hydrogenation of myrcene catalyzed by complexes of ruthenium, chromium, iridium and rhodium. J.Mol.Catl.A: Chem, 239,10. (2005).

27. Bond, G.C; Louis,C y Thompson, D.T.(2006). Catalysis by Gold. (1a. ed;vol.6).Londres. Imperial. College.Press.

28. Corain, B; Schimid, G y Toshima, N. (2008). Metal nanoclusters in catalysis and materials science the issue of control. Ansterdam: Elsevier.

29. R. Zanella. Aplicación de los nanomateriales en catálisis. Mundo nano. Vol.7, $\mathrm{n}^{\circ} 12$, (2014)

30. xxx28. J. Dupont y J. Scholten. On the structural and surface properties of transition-metal nanoparticles in ionic liquids. Chem. Soc. Rev, 39, 17801804, (2010).

31. S. Kang, K. Char, Y. Kang. Chem Mater 20:1308-1311, (2008).

32. J. Dupont, J. Braz. Chem.Soc.15, 341. (2004).

33. P. Migowski, G. Machado, S. Texeira., A. Traverse, J. Dupont. Phys.Chem. 9 (2007) 4814.

34. a) Redel. E, Thomann. R, Janiak. C. Inorg.Chem.47(2008)14; b) Redel. E, Thomann. R, Janiak. C. Chem.Commun (2008) 1789.

35. Gutel.T, Garcia-Anton. J, Pelzer.K, Philippot. K, Santimi.C.C, Chauvin.Y, Chaudret.B, Basset. J.M. J.Mater.Chem.17(2007)3290.

36. a) Fonseca. G.S, Machado.G, Texeira. S.R, Fecher. G.H, Marais. J, Alves.M.C.M, Dupont.J, J.Colloid interface Sci. 301(2006)193; b) Ren.L, Meng.L, Lu.Q, Fei. Z, Dyson. P.J. J.Colloid interface Sci. 323 (2008) 260.

37. Dupont. J. Acc.Chem.Res (2011), 44, 1223-1231.

38. Dupont. J, Sholten. J.D. Chem.Soc.Rev. (2010), 39, 1780-1804.

39. Wegner,S y Janiak, C. Metal nanoparticles in ionic liquids. Top Curr Chem (Z), 375:65. (2017).

40. J. A. Widegren, M. A. Bennett and R. G. Finke, J. Am. Chem. Soc, 125 , 10301, (2003).

41. A. Reay and I. Fairlamb. Catalytic C-H bond functionalisation chemistry: the case for quasi-heterogeneous catalysis. Chem. Commun.1-19, (2005). 